\title{
RNA-Binding Protein 6
}

National Cancer Institute

\section{Source}

National Cancer Institute. RNA-Binding Protein 6. NCI Thesaurus. Code C29833.

RNA-binding protein 6 (1123 aa, $\sim 129 \mathrm{kDa}$ ) is encoded by the human RBM6 gene. This protein is involved in RNA recognition. 